\title{
Monitoring and analysis of Tabuk sewage treatmentplant
}

\author{
Ayman H. Al-Momani \\ Head of Civil Engineering Department,University of Tabuk, Tabuk, Saudi Arabia
}

\section{Email address:}

aal-momani@ut.edu.sa

\section{To cite this article:}

Ayman H. Al-Momani. Monitoring and Analysis of Tabuk Sewage Treatmentplant. International Journal of Environmental Monitoring and Analysis. Vol. 1, No. 3, 2013, pp.84-90. doi: 10.11648/j.ijema.20130103.12

\begin{abstract}
The increasing need for water in the arid areas of the world has resulted in the emergence of wastewater application for agriculture and landscape. This study aims to determine the mechanism and the functioning of waste water purification plant in the city of Tabuk, and see if the water was purified by the station impacted positively on the environment surrounding human beings, as well as determine if we can re-use the treated water in the various human uses. The objective of this research was to establish the operational parameters of Influent and effluent such as temperature, $\mathrm{pH}$, TSS, biochemical oxygen demand (BOD), chemical oxygen demand (COD), dissolved organic carbon (DOC), TN, TP, and oil \& grease $(\mathrm{O} \& \mathrm{G})$. Three years of data (2010-2012) were manually collected at both the inlet and outlet. The results indicated that the $\mathrm{pH}$ was in between 6.213 to 7.493. Municipal wastewater showed that the TSS, BOD and COD were within the Saudi standards.It was revealed from the performance study that efficiency of the treatment plant was good with respect to removal of parameters like total suspended solids, BOD and COD. The overall performance of the wastewater treatment plant effectively removed TC, FC, and FS. The treated effluent can be safely discharged or it can be reused for irrigation of a fodder crops, golf course, green way, parks, for landscaping and for groundwater recharge. This work has confirmed that, the plant efficiency is comparable to that of other Saudi's wastewater plants using the same or different type of biological treatment. Finally, based on this analysis, we proceed to identify niches in which wastewater reuse could be increased.
\end{abstract}

Keywords: Tabuk Wastewater, Monitoring and Analysis, Pollution, Effluent, Reuse, Total Dissolved Solids, Chemical Oxygen Demand, Biochemical Oxygen Demand

\section{Introduction}

Like many countries in the world, water scarcity is becoming a major problem in Saudi Arabia. Watercourses receive pollution from many different sources, which vary both in strength and volume. "Discharge of either raw or treated sewage from towns and villages; discharge from manufacturing or industrial plants; run-off from agricultural land; and leachates from solid waste disposal sites" these sites of pollution have problems so that a solution is sought (Horan, 1990). Scarcity of water, the need for energy and food are forcing us to explore the feasibility of wastewater recycling and resource recovery (De la Nou" e and De Pauw, 1988).

The rapid growth of human population, rapid industrialization, quest for material comforts and new life styles demanding a variety of products and amenities, have led to "the environmental pollution" which has become Global phenomenon. The latest census of 2007 reveals that KSA's populations is about 23.9 million and are projected to grow up to 31.5 and 69.7 million in $2020 \mathrm{AD}$ and 2060 AD respectively (MWE, 2012). The fresh water demand for irrigation, domestic as well as industrial use will shoots up consequently. Thus there is a wide gap between the demand and supply of water.

Freshwater has become a scare commodity due to over exploitation and pollution (Ghose and Basu 1968; Gupta and Shukle; 2006; Patil and Tijare, 2001; Singh and Mathur, 2005). Pollution is caused when a change in the physical, chemical or biological condition in the environment harmfully affect quality of human life including other animals' life and plant (Lowel and Thompson, 1992; Okoye et al., 2002). Industrial, sewage, municipal wastes are been continuously added to water bodies hence affect the physiochemical quality of water making them unfit for use of livestock and other organisms (Dwivedi and Pandey, 2002).

Wastewater comprises a huge range of potential contaminants and concentration discharged by domestic residence, commercial properties, industry and agriculture. 
Sewage is subset of wastewater categorized in terms of its physical, chemical and biological composition. In Saudi Arabia, wastewater is mainly generated from residential household, public toilet, laundries and restaurants. As populations increase, it places more pressure on the environment and threatening sources of fresh water supplies, it was recognized that the problem of 'human waste' needed proper management. Wastewater treatment plants are rapidly increasing in Saudi Arabia as a response to the increasing demands for better and more effective sanitation services resulting from the country's remarkable economic growth.

Saudi Arabia collects and treats 672 million cubic meter of wastewater per day but less than $20 \%$ is ultimately reused (Al-Musallam, 2006). Although in 1999 there were 30 major sewage treatment facilities with secondary, tertiary, and advanced levels of treatment and a total design capacity of 1,426,000 m3/day (Jimenez and Asano, 2008), a significant challenge continues to exist in the low overall sewerage rate of $37 \%$ (Qadir et al., 2010). Wastewater disposal had previously been limited to cesspits in small towns and rural areas, with untreated wastewater often discharged into wadis or into the sea (Abu-Rizaiza, 1999), but the recently created National Water Company (NWC) is to invest \$23 billion into Saudi Arabia's sewage collection and treatment infrastructure over the next two decades and aims to increase wastewater network coverage to $100 \%$ through public private partnership (PPP) (Saudi Gazette, 2010). Consequently, Saudi Arabia is anticipated to become the third-largest water reuse market in the world after the United States and China (Saudi Gazette, 2010).

Recycling of treated or partially treated wastewater is a common practice in many countries. A non-exhaustive literature review undertaken to assess the extent of the practice in specific regions of the world, indicate that in Latin America a total of more than 500,000 ha of agricultural land is irrigated with wastewater (Chanduvi, 2000). Of these 350,000 ha are in Mexico alone (Peasey et al., 2000). In the near eastern region, which is one of the most water scarce regions in the world, documented evidence shows that wastewater irrigation is extensive notably in Saudi Arabia, Kuwait, Jordan, Tunisia and Morocco (AQUASTAT- FAO database, 1997). In countries of the former Soviet Union, literature indicates that at least 70,100 ha are irrigated with wastewater (FAO Water Reports, 1997). These examples are indicative of the importance of wastewater recycling both in developing and developed contexts. Extensive use has also been documented in Northern America, Europe and Australia (Angelakis et al., 1999; Crook, 2003; Lallana et al., 2001).

In the last decade, increased attention has been given to the physical and biological integrity of our nation's water bodies because of the indispensable value and role in people's lives. The reuse of wastewater is one of the main options being considered as a new source of water in regions where water is scarce. This study has been carried out to assess the quality of municipal wastewater of Tabuk city, Saudi Arabia therefore a continuous periodical monitoring of water quality is necessary, particularly in the area of industrial settlements, so that appropriate steps may be taken for water resource management practices.

In this regard, disposal of inadequately treated wastewater is one of the main sources of pathogens in the environment, more so in a water scarce country like Saudi Arabia. Water pollution by effluent has become a question of considerable public and scientific concern in the light of evidence of their extreme toxicity to human health and to biological ecosystems (Katsuro et al., 2004). Hence there should be regular assessment of these sewage effluents to ensure that adequate measures are taken to reduce pollution level to the minimum.

Assessment of water and wastewater is very crucial to safeguard public health and the environment. However, water quality data on fresh and marine waters in Saudi Arabia are still sparse and uncoordinated. Therefore, monitoring these parameters is important for safety assessment of the environment and human public health in particular. Polluted environment and water contaminated by effluent from various sources is associated with heavy disease burden and this could influence the current shorter life expectancy in the developing countries compared with developed nation (WHO, 2002).In carrying out this study the methodology adopted four main stages from the literature review to understand and profound knowledge on the research topic, selection of study area, collection of data, data analysis, research finding, discussion, conclusion and recommendation related to the scope study.

\section{Study Area}

\subsection{Location}

The Tabuk area is located in the northwest region of Saudi Arabia. Tabuk is a transit point for trade caravans passing from south to north and vice versa. It has resumed its role as a town combining a glorious past with modern achievements. Tabuk lies roughly between latitudes $24^{\circ} 30^{\prime}$ and 30o $00^{\prime}$ north, and longitudes $34^{\circ} 45^{\prime}$ ' and 40o $00^{\prime}$ ' east. The study area used for this research is located between latitudes $27^{\circ} 30^{\prime}$ and $29^{\circ} 00^{\prime}$ north, and longitudes $35^{\circ} 30^{\prime}$ and 37o 30' east. Tabuk region is one of the largest regions in Saudi Arabia, which covers an area of $139,000 \mathrm{~km} 2$, and corresponds to about $7 \%$ of the country's total area. The total area of Tabuk city is $\left(35,000 \mathrm{~km}^{2}\right)$ divided into 283 meshes as the built-up area of the city is $283 \mathrm{~km}^{2}$. Most of the remaining areas are farms and desert (Al-Momani, 2012).

\subsection{Climatology}

The study area is affected by the Mediterranean climate. It is subjected yearly to Mediterranean Sea effects, especially the depressions that cause winter rainfall. The area is subjected also to Indian depressions that produce the northern trade winds, contributing to increased 
temperatures in the summer. Table 1.shows the average minimum and maximum values of temperatures. A rapid increase in temperature starts in April and continues through September. In November, the temperature begins to decrease as the winter season approaches. However, the average temperatures in January have low values of $17.6^{\circ} \mathrm{C}$ while $38.7^{\circ} \mathrm{C}$ and higher values are recorded in August. The average annual rainfall is about $20 \mathrm{~mm}$, while the annual evaporation is almost $40 \mathrm{~mm}$.

Table 1. Average High/Low Temperature for Tabuk.

\begin{tabular}{|c|c|c|c|c|c|c|c|c|c|c|c|}
\hline Jan & Feb & Mar & Apr & May & Jun & Jul & Aug & Sep & Oct & Nov & Dec \\
\hline $18^{\circ} \mathrm{c}$ & $20^{\circ} \mathrm{c}$ & $25^{\circ} \mathrm{c}$ & $31^{\circ} \mathrm{c}$ & $35^{\circ} \mathrm{c}$ & $38^{\circ} \mathrm{c}$ & $39^{\circ} \mathrm{c}$ & $39^{\circ} \mathrm{c}$ & $37^{\circ} \mathrm{c}$ & $32^{\circ} \mathrm{c}$ & $25^{\circ} \mathrm{c}$ & $20^{\circ} \mathrm{C}$ \\
\hline $4^{\circ} \mathrm{c}$ & $5^{\circ} \mathrm{c}$ & $9^{\circ} \mathrm{c}$ & $14^{\circ} \mathrm{c}$ & $19^{\circ} \mathrm{c}$ & $22^{\circ} \mathrm{c}$ & $24^{\circ} \mathrm{c}$ & $24^{\circ} \mathrm{c}$ & $21^{\circ} \mathrm{c}$ & $17^{\circ} \mathrm{c}$ & $10^{\circ} \mathrm{c}$ & $5^{\circ} \mathrm{c}$ \\
\hline
\end{tabular}

The impurities of the domestic wastewater can be removed by conventional and advanced treatments for the purposes of discharge or treated water reuse. The treatment processes consisted of primary treatment (physical process) and secondary treatment (biological process). Primary and secondary treatments reduce the majority of contaminations found in wastewater (Sonune and Ghate, 2004).

\subsection{Plant Description and Design Criteria of Tabuk Wastewater Treatment Plant}

The Tabuk wastewater treatment facility is situated at geographical coordinates of: $28^{\circ} 34^{\prime} 37^{\prime \prime} \mathrm{N} 36^{\circ} 37^{\prime} 23^{\prime \prime} \mathrm{E}$ and approximately $17 \mathrm{~km}$ North of the city center. The plant which has a design capacity of the plant is $60,000 \mathrm{~m} 3 /$ day receives domestic sewage, some light industrial wastewater, as well as run-off water. At the beginning of the plant operation, half of the design capacity had been used until
February 2004. Since then, the treatment plant has been operating with full capacity. The plant uses a conventional activated sludge system for biological treatment.

The Wastewater Facility is designed to treat 60,000 $\mathrm{m} 3 /$ day of wastewater. The peak flow of $109,000 \mathrm{~m} 3 / \mathrm{d}$ with influent BOD of $270 \mathrm{mg} / \mathrm{L}$ and $\mathrm{SS}$ of $200 \mathrm{mg} / \mathrm{L}$. The effluent concentrations should not exceed $20 \mathrm{mg} / \mathrm{L}$ for both BOD and SS. Organic and nitrogen compounds in the incoming wastewater are stabilized by a concentrated population of micro-organisms maintained within the facility. Additionally, phosphorus is removed from the wastewater through the means of coagulation and precipitation of phosphorus compounds. Following the BNR process, the treated water is then filtered, disinfected and de-chlorinated prior to being discharged from the facility.

Table 2. Physicochemical properties of the wastewater column in the WTP of Tabuk

\begin{tabular}{|c|c|c|c|c|c|c|c|c|c|c|c|c|c|c|c|c|c|c|c|c|c|c|c|c|c|}
\hline \multicolumn{12}{|c|}{ Raw sewage } & \multicolumn{14}{|c|}{ Treated sewage } \\
\hline \multicolumn{2}{|c|}{ Design parameters } & 45 & 10 & 00 & 200 & 0 & 0 & 5 & 2. & 0 & 200 & 35 & 6--9 & 00 & 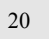 & 50 & $>4$ & 80 & 40 & 5 & $* * *$ & 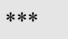 & 00 & 1 & 500 \\
\hline \multirow[t]{9}{*}{ 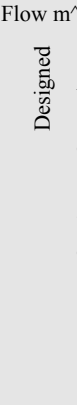 } & Actual & 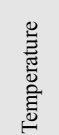 & $\Xi$ & $\stackrel{\mathscr{C}}{\circ}$ & $\stackrel{\omega}{\hat{\leftrightarrow}}$ & 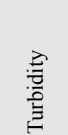 & ْ̊. & ○ी. & $\begin{array}{l}\frac{0}{\pi} \\
\frac{\pi}{2} \\
\frac{0}{2} \\
\frac{0}{2}\end{array}$ & 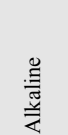 & 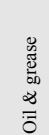 & 莺 & 全 & $\stackrel{\infty}{\circ}$ & & 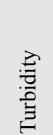 & $\stackrel{0}{\circ}$ & ْ̊. & ْి & 营 & 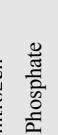 & 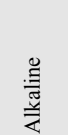 & 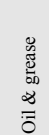 & 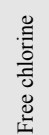 & 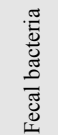 \\
\hline & 9024 & 23.6 & 7.2 & 1397.3 & 270.0 & 221.7 & 607.2 & 240.0 & 24.9 & 74.3 & 21.3 & 22.6 & 7.5 & 1378.5 & 44.6 & 43.4 & 3.3 & 70.2 & 34.4 & 3.3 & 5.3 & 277.8 & 0.1 & 0.2 & 13.7 \\
\hline & 87887 & .7 & 6.0 & 3 & 45.0 & 230.0 & 3.3 & 5.0 & 20.7 & 2.0 & 18.0 & 18.9 & 6.2 & 8 & 1 & 36.1 & 2.8 & 59.0 & 29.1 & 2.8 & 4.4 & & 0.1 & 0.2 & 5.3 \\
\hline & 79379 & .0 & 6.2 & 1230.0 & 230.0 & 220.0 & 522.7 & 240.0 & 21.4 & 4.5 & 18.8 & 20.1 & 6.5 & 2 & 6 & 37.4 & 2.7 & 61.2 & 31.2 & 2.8 & 4.6 & & 0.1 & 0.2 & 99.0 \\
\hline & 92216 & 1.1 & 6.0 & 1187.7 & 260.0 & 230.0 & 499.7 & 225.0 & 20.4 & 311.5 & 17.8 & 20.3 & 6.2 & 1176.8 & 45.8 & 43.7 & 2.6 & 62.2 & 34.5 & 2.7 & 4.5 & .7 & 0.1 & 0.2 & 5.3 \\
\hline & & & 6.0 & & 30.0 & 224.0 & & & 3 & & & 20.7 & & & & 55.9 & 2.6 & 8 & 41.3 & 2.6 & 4.6 & & 0.2 & 0.2 & 5.3 \\
\hline & 12 & 5 & 6. & 7.3 & 240.0 & 232.0 & 477.3 & 22 & 20.2 & 7 & 17.8 & 21. & 6.2 & & 57.8 & 55.9 & 2.5 & 5 & 40.8 & 2.6 & 4.6 & & 0.2 & 0.2 & 95.3 \\
\hline & 122845 & 25.3 & 6.5 & 1244.0 & 255.0 & 230.0 & 515.7 & 240.0 & 20.9 & 328.8 & 18.2 & 24.4 & 6.5 & 1232.2 & 56.3 & 56.0 & 2.7 & 66.7 & 39.7 & 2.8 & 4.7 & 2 & 0.2 & 0.2 & 95.3 \\
\hline & & 27.4 & 6.0 & 1198.7 & 270.0 & 240.0 & 497.3 & 250.0 & 20.0 & 16.0 & 17.5 & 26.6 & 6.2 & 1186.5 & 53.8 & 54.1 & 2.6 & 64.5 & 37.0 & 2.6 & 4.5 & 32.7 & 0.2 & 0.2 & 91.7 \\
\hline \multirow{5}{*}{ 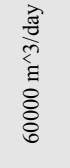 } & 122287 & 27.6 & 6.0 & 1197.0 & 240.0 & 225.0 & 497.3 & 225.0 & 20.0 & 315.7 & 17. & 26.7 & 0.2 & & & 53.4 & 2.6 & 63 & 36.6 & 2.7 & 4.5 & & 2 & 0.2 & 91.7 \\
\hline & 112804 & 25.5 & 6.0 & 9.5 & 236.0 & 215.0 & 36.0 & 14.0 & 20.0 & 8 & 17.3 & 24.6 & 62 & 7.3 & 52.7 & 53.0 & 2.6 & 62.9 & 36.3 & 2.7 & 4.6 & .5 & .2 & 0.2 & 91.7 \\
\hline & 119986 & 23.4 & 6.0 & 1202.0 & 240.0 & 220.0 & 474.7 & 240.0 & 20.0 & 316.0 & 17.2 & 22.6 & 6.2 & 1189.3 & 52.6 & 52.6 & 2.5 & 62.0 & 36.0 & 2.6 & 4.6 & 232.3 & 0.2 & 0.2 & 91.7 \\
\hline & 93278 & 22.8 & 6.5 & 1250.3 & 265.0 & 245.0 & 514.0 & 230.0 & 20.9 & 328.7 & 17.8 & 21.9 & 6.5 & 1237.3 & 36.1 & 36.5 & 2.7 & 51.3 & 27.6 & 2.8 & 4.8 & 241.7 & 0.2 & 0.2 & 95.3 \\
\hline & 122845 & 27.6 & 7.2 & 1397.3 & 270.0 & 245.0 & 607.2 & 250.0 & 24.9 & 374.3 & 21.3 & 26.7 & 7.5 & 1378.5 & 58.3 & 56.0 & 3.3 & 70.2 & 41.3 & 3.3 & 5.3 & 277.8 & 0.2 & 0.2 & 113.7 \\
\hline \multirow{2}{*}{ 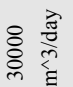 } & 104541 & 23.5 & 6.2 & 1221.7 & 248.4 & 227.7 & 508.0 & 230.8 & 20.8 & 322.2 & 18.1 & 22.6 & 6.4 & 1208.8 & 48.9 & 48.2 & 2.7 & 63.1 & 35.4 & 2.7 & 4.6 & 3 & .2 & 0.2 & 95.9 \\
\hline & 79379.0 & 19.7 & 6.0 & 1159.3 & 230.0 & 215.0 & 474.7 & 210.0 & 20.0 & 311.2 & 17.2 & 18.9 & 6.2 & 1143.8 & 36.1 & 36.1 & 2.5 & 51.3 & 27.6 & 2.6 & 4.4 & 231.3 & 0.1 & 0.2 & 91.7 \\
\hline
\end{tabular}

\section{Materials and Methods}

Three years of data (2010-2012) were manually collected at both the inlet and outlet. Typical water quality parameters were measured, including TSS, biochemical oxygen demand (BOD), chemical oxygen demand (COD), dissolved organic carbon (DOC), TN, TP, heavy metals (zinc, lead, etc.), and oil \& grease (O\&G). Analyses of these parameters were performed in accordance with international standard methods for wastewater analyses (Clesceri et al., 2005). Yearly data records including means, maximum and minimum values, mean and efficiency of removal are shown on Table 2. All field meters and equipments were checked and calibrated according to the manufactures specification.

\subsection{Efficiency of Removal}

The qualities of influents and effluents were measured at 
these two points to determine the efficiency of the treatment plant in renovating the sewage. There are several different types of efficiencies that play a role in water and wastewater treatment. One of the most important in the wastewater field is the efficiency of removal, which involves the removal of a substance. The efficiency of removal can be calculated using the following formula:

$$
F_{r}=\frac{\text { Initial Amount - Reduced Amount }}{\text { Initial Amount }} \times 100 \%
$$

Table 3. Efficiency of Removal

\begin{tabular}{llll}
\hline PHOSPH. REMOVAL & $78 \%$ & BOD REMOVAL & $85 \%$ \\
TURBI. REMOVAL & $79 \%$ & COD REMOVAL & $88 \%$ \\
OIL\&GREAS REMOVAL & $99 \%$ & DO (mg/l) & 3 \\
FLOW(average) m3/day & 104541.1 & TSS REMOVAL & $80 \%$ \\
\hline
\end{tabular}

A year around variation of BOD and COD was measured from Tabuk wastewater treatment plant. Relationships between BOD and COD were discussed on the raw sewage and treated sewage water.

\section{Results and Discussion}

The properties of the sewage, after it was treated and disinfected and the corresponding irrigation standards are shown in Table 2. The data in the table are the average values for the quality of both treated and untreated sewage. Three years of data (2010-2012) were manually collected. During this period, the average daily flow of domestic wastewater treatment in the city of Tabuk was $105840.81 \mathrm{~m} 3 /$ day. The plant was over the average design capacity but under the peak design capacity.

A minor variation of temperature was recorded in the years of investigation. Thehigher average seasonal value of temperature that is $30.570 \mathrm{C}$ in May 2009 was recorded in thesample. The observed values of temperature indicate that the municipal wastewater qualitywould be certainly affected by this parameter. Among the various water parameters, temperatureis one of the most important factors having profound influence on the biotic communities.

A minor variation of temperature was recorded during the years of investigation. The higher average seasonal value of temperature was 39C 0 in July and August. The observed values of temperature indicate that the municipal wastewater quality would be certainly affected by this parameter. Among the various water parameters, temperature is one of the most important factors having profound influence on the biotic communities.One of the important parameters for evaluation of the quality of wastewater is $\mathrm{pH}$ value or acidic or alkaline status. Increase or decrease of this parameter in a wastewater will cause the corrosion and damage of WTP and sewers. This index also plays a significant role in biologic processes of wastewater treatment (Chitnisa, 2004). In this research the maximum $\mathrm{pH}$ of raw wastewater was 7.207 and mean value was 6.0.
According to the standards of the MWE of KSA, the acceptable level of $\mathrm{pH}$ to discharge of effluent to receiving water is 6.5 to 8.4 , considering our study findings it is clear that $\mathrm{pH}$ of studied wastewater plant were compatible with this standards. The turbidity range was from 36.1 to 56.03 NTU. These values indicate that the municipal wastewater is more turbid, much higher than the recommended values of $5 \mathrm{NTU}$ for recreation and irrigation water.

The treatment capability of the system was evaluated based on BOD, COD, DO, TSS, Turbidly, phosphate, and oil \& grease removal. The overall average removal efficiency of the system is shown in Table 2. The highest removal efficiency was achieved for oil and grease $(O \& G)$ with $99 \%$ removal. The other pollutant parameters were more than $80 \%$ removal efficiencies. Average removals for COD and BOD were $88 \%$ and $85 \%$ respectively. The corresponding values for the removal efficiency of SS, pathogenic bacteria and turbidity were $80 \%, 91.67 \%$, and $79 \%$ respectively. In summary, the mean values of removal showed fairly high removal efficiency for various wastewater constituents. WHO guidelines recommend that an effluent is suitable for unrestricted irrigation when the fecal coliforms (FC) do not exceed $1000 \mathrm{FC}$ per $100 \mathrm{ml}$ (WHO 1989); therefore, this effluent can be safely used for both unrestricted and restricted irrigation.

Maximum and minimum of TSS in raw wastewater were found 270 and $230 \mathrm{mgL}-1$, respectively, and the mean concentration of TSS in raw wastewater was $248 \mathrm{mgL}-1$. The mean TSS of domestic wastewater is $248 \mathrm{mgL}-1$. The mean concentration of TSS in treated waste was $49 \mathrm{mgL}-1$. Based on our study findings, the mean removal of TSS was $80 \%$. The BOD is an indication of the organic load of municipal wastewater. BOD varied from $210 \mathrm{mg} / 1$ to 250 $\mathrm{mg} / \mathrm{l}$. The COD is another parameter used to characterize the organic strength of municipal wastewater. COD varied from $474.7 \mathrm{mg} / 1$ to $607.2 \mathrm{mg} / \mathrm{l}$. The mean concentration of BOD5 and COD was measured as 231 and $508 \mathrm{mgL}-1$ in raw wastewater while its 35 and $63 \mathrm{mgL}-1$ in the treated wastewater, respectively. In terms of wastewater strength, Tchobanoglous et al. ( 2004) stated that the mean concentration of BOD and COD in domestic wastewater, are in the range of 110 to 350 and 250 to $800 \mathrm{mgL}-1$. In Tabuk wastewater, the mean concentration of BOD and COD in this study falls within this range and in agreement with several studies such as Hamoda et al. (2004), AlJlil,(2009) and Al-Turki (2010) . The mean removal of BOD and COD were $85 \%$, and $88 \%$, respectively. Findings of a study in Greece reported that the wastewater treatment plant of the city of Thessaloniki (northern Greece) shows that removal of persistent organic pollutants (POPs) during the conventional activated sludge treatment process were between 65 to $91 \%$ through-out the whole treatment process (Katsoyiannis and Samara, 2004).

Coliforms bacteria are one of the significant indicators for microbial quality assessment of wastewater. According to the MWE standards for effluent reuse, the permissible limit of total coliforms bacteria in wastewater effluent is 
1000 MPN per $100 \mathrm{ml}$ of effluent (MoWE, 2012). The mean number of TC has been more than $4 \times 107 F C U 100 \mathrm{~mL}-1$. Fecal Coliform (FC) was found 4.5x106FCU100mL-1. In chlorinated effluent TC and FC counts were substantially reduced to negligible counts (1CFU $100 \mathrm{~mL}-1)$ indicating that disinfection process is highly effective and can inactivate both TC and FC in the tertiary effluent. The regulation required by the Ministry of Water and Electricity for the FC in tertiary effluent should not exceed 2.2 CFU100mL-1 for unrestricted irrigation. This result indicates that there is no microbial contamination hazard of the effluent reuse for irrigation. Testing and regular checkups for microbial quality of the effluent should be performed as part of a regular integrated monitoring program designed to minimize the risk associated with reuse. Therefore, a regular regime of monitoring is essential if good quality effluents are to be achieved and maintained. It is recommended that this is done at least monthly.

\section{Conclusion}

In Tabuk as in many areas of Saudi Arabia the full utilization of treated wastewater remains in the early stages, much of the treated wastewater is discharged to land. The volume of reuse of treated wastewater is still far less than the volume of treated wastewater discharged. The primary use for treated wastewater is for municipal landscaping. Due to the long distance between treatment plants and the point in use for irrigation, the irrigation use is very limited except for some specialized development schemes. In our study despite the chlorination systems, the mean chlorine residual in effluent were less than the standard level of 1 mgL-1. The mean concentrations of TSS, BOD and COD in wastewater effluent were less than reuse standard of the MWE. This indicates efficient removal of mentioned parameters from the Tabuk wastewater plant. For TC bacteria, the mean value in effluent of WTP was in acceptable levels for reuse. The performance studies on the Tabuk Sewage Treatment Plant indicated a positive efficiency of the system. The overall efficiency is in the order TDS $<$ TSS $<$ BOD $<$ COD. The treated effluent can be safely discharged or can be reused for irrigation and groundwater recharge

Considering the large water deficit affecting the region, wastewater reuse in Saudi Arabia has a high potential to help alleviate this problem. The percentage contribution of treated effluents was below targeted share. Therefore, improvements in wastewater treatment techniques should be made to utilize this wastewater. The reuse of effluents in irrigation should be maximized to alleviate the burden on the fossil ground water supply and the water consumed by irrigation should be rationalized without much affect on agricultural production. To delineate optimization of treated effluents, the interaction between the responsible governmental institutions must be addressed. This may eventually ease the burden and pressure on the limited water resources. For all of these reasons, wastewater recycling usually requires a long-term government commitment. Greater effort should be devoted in producing good quality treated wastewater to be used for nonrestrictive irrigation. Public awareness, regulatory compliance, and monitoring should be reinforced. Neglecting monitoring procedures and/or performing monitoring irregularly and incorrectly could have serious negative impacts on health, water quality, and environment.

\section{Acknowledgements}

The author would like to thank Deanship of Scientific Research at Tabuk University for providing financial support for this research in the form of a senior research fellowship.

\section{References}

[1] Al-Momani, Ayman H.,Management of Flood Risks at the City Of Tabuk, 4th International Disaster and Risk Conference IDRC Davos 2012.

[2] Abu-Rizaiza, O.S., 1999. Modification of the standards of wastewater reuse in Saudi Arabia. Water Research 33, $2601 \mathrm{e} 2608$.

[3] Alabdula'aly, A.I., 1997. Trace metals in Riyadh public water supplies. The Arabian Journal for Science and Engineering 22, 165.

[4] Al-Jlil, S.A., 2009 COD and BOD reduction of domestic wastewater using activated sludge, sand filters and activated carbon in Saudi Arabia. Biotechnology, 9: 473-477.

[5] Al-Musallam, L., 2006. Water and Wastewater Privatization in Saudi Arabia, SAWEA 2006 Workshop: Privatization and Outsourcing of Water and Wastewater.

[6] Al-Rehaili, A.M., 1997. Municipal wastewater treatment and reuse in Saudi Arabia. Arabian J. Sci. Eng. 22 (1C), $143-152$.

[7] Al-Turki, A., 2003. Swage water quality of Unizah wastewater treatment plant and its suitability for irrigation. Journal of Agricultural science, Mansoura University, 28: $5861-5872$.

[8] Al-Masry,W.A., and M.A. El-Kady, 2007. Advanced Environmental Assessment And Emission Control Of Generating Power Plants, Proceedings of the Seventh Saudi Engineering Conference, Volume II, Riyadh 2-5, December 2007.

[9] Angelakis, A.N., Marecos, M.H.F., Bontoux, L., Asano, T., 1999. The status of wastewater re-use practice in the Mediterranean basin need for guidelines. Water Resour. 33 (10), 2201-2217.

[10] Al-Rehaili, Abdullah M., 1997. Municipal wastewater treatment and reuse in Saudi Arabia. The Arabian Journal for Science and Engineering Vol.22, No.10, 143.

[11] Bahri, A. (2008). "Water reuse in Middle Eastern and North African countries." In Water Reuse: An international Survey of Current Practice, Issues and Needs (eds. B. Jimenez and T. Asano). IWA Publishing, London. 
[12] Bahri, A. (2002). "Water Reuse in Tunisia: Stakes and Prospects." In Versunemaîtrise des impacts environnementaux de l'irrigation: Atelier du PCSI. Montpellier, France: CEMAGREF, CIRAD, IRD, Cédérom du CIRAD.

[13] Chanduvi, F., 2000. Worldwide status of wastewater treatment in irrigation. In: Paper Presented at Agroenviron 2000. Proceedings of the Second International Symposium on New Technologies for Environmental Monitoring and Agro Applications.

[14] Clesceri LS, Greenberg AE, Eaton AD (2005). Standard method for examination of water and wastewater. APHA, WPCF, AWWA, 21th ed., Washington DC.

[15] Crites RW, Tchobanoglous G. Small and Decentralized Wastewater Management Systems. McGraw-Hill. 1998; 520.

[16] Choukr-Allah, R., and Hamdy, A. (2004). "Wastewater Treatment and Reuse in Mediterranean Region as a Potential Resource for Drought Mitigation." http://ressources.ciheam.org/om/pdf/a66/00800302.pdf [Accessed December12, 2012].

[17] Crook, J., 2003. Water reuse - an overview. Keynote Speech Presented at MED-REUNET 1 Project, International Seminar on Wastewater Reclamation and Reuse, Izmir, Turkey, 25-26 September 2003. Website: Mediterranean network on wastewater reclamation and reuse. www.medreunet.com.

[18] De la Nou" e, J., De Pauw, N., 1988. The potential of microalgal biotechnology. A review of production and uses of microalgae. Biotechnol. Adv. 6, 725-770.

[19] ESCWA, 2001a. Energy Options for Water Desalination in Selected ESCWA Member Countries. United Nations, New York.

[20] ESCWA, 2001b. The Role of DesalinatedWater in Augmentation of theWater Supply in Selected ESCWA Member Countries. United Nations, New York.

[21] Euromonitor International, 2011. Sewage and Sanitation in Saudi Arabia: Industrial Report.

[22] FAO, 2008. Irrigation in the Middle East Region in Figures: AQUASTAT Survey e2008, FAO Water Reports. Food and Agriculture Organization of the United Nations, Rome, 423 p.

[23] Gray N.F.(1989), Biology of Wastewater Treatment, Oxford University Press, New York

[24] Gregory, A., 2000. Strategic direction of water recycling in Sydney. In: Proceeding of the First Symposium Water Recycling, Australia, Adelaide, 19-20 October, pp. 35-41.

[25] Hamoda, M.F., 2004. Water strategies and potential of water reuse in the south Mediterranean countries. Desalination 165, $31 \mathrm{e} 41$.

[26] Hamoda, M.F., I., Al-Ghusain and N.Z., Al-Mutair, 2004, Sand filtration of wastewater for tertiary treatment and reuse. Desalination, 164:203 - 211.

[27] Horan, N.J., 1990. Biological Wastewater Treatment Systems. Theory and operation. John Wiley and Sons Ltd. Baffins Lane, Chickester. West Sussex PO 191 UD, England.
[28] Jimenez, B., Asano, T., 2008. Water Reuse: An International Survey of Current Practice, Issues and Needs. IWA Publishing, London, $631 \mathrm{p}$.

[29] Lallana, C., Krinner, W., Estrela, T., Nixon, S., Leonard, J., Berland, J.M., 2001. Sustainable water use in Europe, Part 2 demand management. In: Environmental Issues. Report No. 19. European Environment Agency.

[30] Lim, S., Chu, W., Phang, S., 2010. Use of Chlorella vulgaris for bioremediation of textile wastewater. J. Bioresour. Technol. 101, 7314-7322.

[31] Mashhady, A.S., 1984. Heavy metals extractable from a calcareous soil treated with sewage sludge. Environmental Pollution (Series B) 8, 5 .

[32] Meli, S., Porto, M., Belligno, A., Bufo, S.A., Mazzatura, A., Scopa, A., 2002. Influence of irrigation with lagooned urban wastewater on chemical and microbiological soil parameters in a citrus orchard under Mediterranean condition. Sci. Total Environ. 285, 69-77.

[33] Ministry of Water \& Electricity, (2012), Supporting Documents

[34] Oron, G., Campos, C., Gillerman, L., Salgot, M., 1999. Wastewater treatment, renovation and reuse for agricultural irrigation in small communities. Agric. Water Manage. 38, 223-234.

[35] Oron, G., DeMalach, J., Hoffman, Z., Manor, Y., 1992. Effect of effluent quality and application method on agriculture productivity and environmental control. Water Sci. Technol. 26 (7-8), 1593-1601.

[36] Peasey, A., Blumenthal, U., Mara, D., Ruiz-Palacios, G., 2000. A review of policy and standards for wastewater reuse in agriculture: a Latin American Perspective. WELL Study, Task No. 68 Part 11

[37] Pereira, L., Oweis, S.T., Zairi, A., 2002. Irrigation management under water scarcity. Agric. Water Manage. 57, 175-206.

[38] Qadir, M., Bahri, A., Sato, T., Al-Karadsheh, E., 2010. Wastewater production, treatment, and irrigation in Middle East and North Africa. Irrigation and Drainage Systems 24, $37 \mathrm{e} 51$.

[39] Qadir, M., Sharma, B.R., Bruggeman, A., Choukr-Allah, R., Karajeh, F., 2007. Non -conventional water resources and opportunities for water augmentation to achieve food security in water scarce countries. Agric. Water Manage. 87 (1), 2-22.

[40] Ramirez-Fuentes, E., Lucho-Constantino, C., EscamillaSilva, E., Dendooven, L., 2002. Characteristics and carbon and nitrogen dynamics in soil irrigated with wastewater for different lengths of time. Bioresour. Technol. 85, 179-187.

[41] Sadiq, M., Hussain, G., 1997. Drinking water quality in Saudi Arabia - an overview. The Arabian Journal for Science and Engineering 22, 153.

[42] SAMC, 2010. Forty Sixth Annual Report: The Latest Economic Developments 1431H (2010G). Saudi Arabian Monetary Agency: Research and Statistics Department, Riyadh.

[43] Saudi Gazette, 2010. Mideast Steps Up Drive for Water 
Reuse Technologies: Kingdom Third Largest Consumer of Water, Saudi Gazette. Saudi Gazette, Jeddah.

[44] Sonune, A. and Ghate, R. (2004). Developments in wastewater treatment methods. Journal of Desalination, 167: $55-63$.

[45] Shetty, S., 2004. Wastewater use in Tunisia: lessons learned and the road ahead. In: Scott, C., Faruqui, N.I., Raschid, L. (Eds.), Wastewater Use in Irrigated Agriculture: Confronting the Livelihood and Environmental Realities. Commonwealth Agricultural Bureau International, OrientLongman, and International Development Research Centre, Ottawa, Canada, pp. 163-171.

[46] Tchobanoglous G, Burton, F, Stensel H (2004). Wastewater engineering: Treatment and Reuse, 4th ed. Metcalf \& Eddy Inc .McGraw- Hill. New York, pp. 30-69.
[47] Tebbutt, T.H.Y., 1983. Principles of water quality control. Pergammon Press, Oxford.

[48] Toze, S., 2006. Reuse of effluent water-benefits and risks. Agric. Water Manage. 80, 147-159.

[49] U.S. Environmental Protection Agency (USEPA). 1992. U.S EPA. Offices of water and wastewater and compliance (Ed.) Guidelines for water reuse. U.S. EPA, Washington. WA State Water Strategy.

[50] WHO, 1989. Health guidelines for the use of wastewater in agriculture and aquaculture. Technical report series no. 778 . World Health Organization, Geneva.

[51] World Bank, 1996. From Scarcity to Security, Averting a Water Crisis in the Middle East and North Africa. The World Bank, Washington, DC. 